\title{
The Concept of Dance Composition East-West Meeting
}

\author{
Ayo Sunaryo* \\ Universitas Pendidikan Indonesia \\ Bandung, Indonesia \\ *ayosekolah@upi.edu
}

\begin{abstract}
The purpose of this paper is to analyze the steps for creating dance compositions, both from the text and the context. This article is an analysis of the dance creation creativity of seven world dance choreographers, namely: Brenda Pugh McCutchen, Anne Green Gilbert, Alma Hawkins, Larry Lavender, Sardono W. Kusumo and Eko Suprianto. The data were obtained from the writings of these figures. The research method uses descriptive analysis and discourse analysis. The result of this research is the dance creation concept of the seven choreographers there are similarities and differences. What they have in common is that they use the same basic aspects of choreography and the difference is; Gilbert, McCutchen, Smith, and Lavender are more inclined towards the process without specifying the formation of the choreography at the stage of forming the choreography because it aims for educational dance which tends to construct, while Alma M. Hawkins, Sardono W. Kusumo, Eko Suprianto are more inclined towards the creation of pure dance very much. pay attention to aesthetic aspects, meaning and symbolization in the steps of its formation because it aims to be a pure artistic work. A new concept was created which is the essence of the choreographers' concepts, namely: ENGKLE consisting of: Enter Environments, Navigation, Googling, Knitting and Validating, Locking and presenting and Evaluation.
\end{abstract} West

Keywords-concept, dance composition, choreographer, East,

\section{INTRODUCTION}

Dance is one of the fields that can be used as an object of artistic creativity. In compiling works of art, creativity is needed to produce good works of art. Creativity is a person's ability to produce new compositions, products or ideas that were not previously known by the composer himself. Compiling works of art can use the existing traditional movement vocabulary or through the search and development of motion that has not been patterned before, namely by exploring motion, improvising motion and composition of movements, namely arranging movements into a dance. Dance is not created instantly, there is a process or steps that must be taken in creating a dance. The process for creating or creating dance works starts from looking for ideas, namely through exploration, improvisation, and formation (composition). The final result can be influenced by internal and external factors such as environmental factors, facilities, skills, identity, originality, and appreciation. The process of dance creativity can be carried out in stages, namely: Exploration, Improvisation, Composition or creation of works of art, namely arranging, arranging and arranging parts so that one another is intertwined into a complete unity. The principles of an artwork that must be present in an artwork are unity, variation, repetition, contrast, transition, sequence, climax, balance, harmony [1]. Meanwhile, in group choreography according to Hadi, there must be basic aspects of group choreography consisting of Unison, Alternate, Canon, Broken [2]. Meanwhile, what is meant by composition or composition is placing, arranging or arranging the parts in such a way that they are related to one another and together form something whole [1]. From this description, it is clear that composition is a part or aspect of creative practice. If a dance is defined as part of the embodiment of expressive forms of motion as a result of a combination of the application of the principles of composition with individuals [1]. If linked with the concept of the Smith method [3], cognitive outcomes, affective outcomes, physical outcomes, social outcomes can be channeled through constructive dance education activities in schools by creating new ideas. Reorganizing objects that have been created and inserting something new. Whereas what is meant by placing, arranging or arranging parts in such a way that one another is related to each other and together forms something intact is Smith's method [3].

\section{RESEARCH SubJeCT AND Methods}

The method used is descriptive analysis method. Descriptive analysis is a method of analysis that aims to describe or explain something as it is [4]. First, the choreographers who could represent East and West were selected and then Brenda Pugh McCutchen, Anne Green Gilbert, Alma Hawkins, Larry Lavender represented the Western choreographers and Sardono W. Kusumo and Eko Suprianto represented the Eastern choreographers. Furthermore, the researcher analyzed the dance creation steps of the choreographers using the discourse analysis method of Deborah Schiffrin [5]. According to Deborah Schiffrin, discourse analysis can be approached with a structural approach, this approach emphasizes the opinion that discourse 
is an interconnected and intertwined constitution [5]. Armed with knowledge, insight, ability and sensitivity, the researcher analyzes the steps of creation, where each choreographer has a different concept of creation. Furthermore, the researcher mixes the choreographer's concepts into the researcher's concept which is the essence of their concepts. The concept of creating East and West dance compositions can be mixed by adding some of the concepts that the researcher does in the concept of creating dance works so that the researcher creates an original concept.

\section{RESULTS AND DISCUSSION}

\section{A. West Chorerografer}

1) Brenda Pugh McCutchen (2006): McCutchen in his book entitled Teaching Dance as Art in Education, consists of 3 chapters [6]. The first is about the notion of educational dance, the second concerns the clarification of 4 contents consisting of a) dancing and performing as dance knowledge, b) creating and composing as techniques for how to make dance works, c) knowing history, culture, and context as knowledge the history of dance, and d) analyzing and critiquing as a study of dance analysis and criticism. While the third part is about presenting educational dance. McCutchen states that choreography is a complex type of composition that expresses ideas, thoughts or concepts in a mostly non-verbal medium of motion [6]. Its purpose is to communicate with meaning and will do. Creative choreography, not imitating. He created a new movement to convey ideas. The emphasis is that the realm of choreography is the realm of discovering movement, creating innovative acts, forms and designs that have not been used before. Rearranging is a very limited form of choreography, therefore improvisation is very important, especially at the basic level of composition.

2) Anne Green Gilbert (2002): Gilbert in his book Creative Dance For All Ages: A Conceptual Approach, The American Alliance for Health, Physical Education states that creative dance combines mastery of movement through the art of expression [7]. He further emphasized that the combination of movement and expressiveness is very important for the harmonization process in expressing creative dance. In theory Gilbert wrote several concepts and basic elements of dance, namely the Concept of Space, Concept of Time, The Concept of Force, Concept of Body, Relationship: body parts to body parts, individual to group, body parts to object, individuals. and group to objects [7]. Balance: on balance / off balance, Concept of Movement) Locomotor and Non Locomotor, Concept of Form. Gilbert states that dance learning in schools must be able to develop cognitive outcomes, affective outcomes, physical outcomes, social outcomes [7]. All of this can be channeled into constructive dance lessons to develop creative movements. The aim is to re-express students' past experiences creatively, and develop imagination, creativity that is developed into the form of dance compositions. Furthermore, he said that dance lessons need to go through the stage of introduction, development and exploration of concepts as well as the development of dance skills and creation. In the concept of creativity, Gilbert says that creative dance combines mastery of motion through the art of expression. It is a combination of the two and is not something that makes creative dance so powerful [7]. Creative dance invites us to find new ideas and foster a creative spirit through dance compositions that can provide motivation and build self-confidence.

3) Alma M. Hawkins (2003): In the creation of works of art, the artists think about many things. It must be based on policies to deal with problems that occur in the process of its creation. Apart from wisdom, the factors of talent and skills also determine the success or failure of a creation. In theory, this work refers to the process of cultivating dance works according to Alma M. Hawkins which is outlined in the book Creating Trough Dance [8]. The book describes the three stages of dance creation, namely the stages of exploration, improvisation, and formation. The stage of exploration or exploration is related to the process of seeking and understanding. The process of searching for space is the search for ideas or ideas that will later be translated into dance works. The improvisation stage is better known as the experimental stage, supporting the previous search results. The last process is forming or forming. Formation is the final process that supports the previous search and experiment process.

4) Jacqueline Smith (1985): Jacqueline Smith named this section with the term "dance stimulus", which is something that arouses thoughts or enthusiasm (will) or motivation for activity (creative process) [3]. There are several kinds of dance stimuli that can be chosen to develop dance material, namely: a) Listen stimulation (auditive), used when the choreographer develops dance material in the form of sounds he hears. b) Visual Stimulus, a choreographer can get stimulation from sight (visual) which is one of the senses that is sharp enough to capture impressions, shapes, surface quality (texture). c) Feeling stimulus, derived from the surface impression of the taste of the material (texture). This tactile stimulus usually does not directly manifest forms of therapeutic motion through a process of association. d) Stimulus of ideas, starting from certain interesting impressions, such as reading a book, dreaming of something, enjoying a beautiful panorama etc. e) Kinesthetic stimulation, derived from a series of various movements made from the results of the improvisation of each individual or group.

5) Larry Lavender (1996): Larry Lavender is a choreographer and lecturer at the University of New Mexico. His book is entitled Dancers Talking Dance Critical Evaluation In The Choreoghrafhy Class. In his explanation, he found a dance creation concept called The ORDER Approach 
to Critical Evaluation, namely five steps or steps in dance creation, namely Observation, Reflection, Discussion, Evaluation, Recomendations and Revisions [9]. If reduced, the concept is like the chart below. The ORDER to Critical Evaluation approach for critical evaluation in choreography classes is called ORDER. Starting with the observation phase, performed carefully and consciously viewing, or attending to, work or art. Next is the writing or reflective period and describing and analyzing aesthetic objects or experiences. Then the reflection that occurs in the Discussion phase. The critical evaluation discussion stage has two parts: First, students share long notes: then they formulate and discuss interpretations of the meaning and importance of dance. The discussion continues at the fourth stage of critical evaluation. In the evaluation stage, here the assessment of the work is articulated and debated. Evaluation is a different step in the critical process because it is important to postpone judgment until the final stage of a critique. Because the choreography process relies heavily on revising and reassessing work in progress, the fifth step of the critical process is a two-part process for job revision. First, participants recommend how the work can be reshaped. Then they assessed that all the choreography teachers' revised dance could prove that viewers who were not trained in critical evaluation tended to formulate interpretations and assessments.

\section{B. East Choreografer}

1) Sardono W. Kusumo: His career as a traditional dancer. In his hometown, at various levels of intensity, he is taught to appreciate, respect the traditional values which serve as the basis of the interrelated collective and conventional context in their creative activities. Living during the struggle for independence, these choreographers were very familiar with the values of individual freedom and ideas of progress. Their creative power is to combine the potential of tradition by expanding and developing pre-existing traditions. His creative process that sided with the values of local genius, and his courage to take risks for radical changes he did, providing a sharing model of creativity for many people art that wrestles with the body. Likewise with the works his experimental work which is organic and open in structure, give him the opportunity to continue to change along with interactions and his creative responses to changing problems and develop according to the soul of the era. This is analogous to the autopoietic phenomenon presented by Maturana and Varela which offers a fundamentally new perspective [10]. This view is a life system that is integratively showing a pattern of selfcreation, the formation of its distinctive structure, and its interactions in life processes that continue to provide sustainability in maintaining its survival energy, in the social systems and ecosystems that support it, in this case its organic autonomy. continues to provide opportunities for various changes that reflect the dynamic anxiety of the creator of the artist.

2) Eko Supriyanto (2015): Eko Supriyanto's dissertation entitled Development of Ideas and Changes in Forms and Creativity of Indonesian Contemporary Dance (1990-2008 Period) at Gadjah Mada University discusses the development of contemporary dance in Indonesia [11]. As for the study of the development and changes in the form and creativity of contemporary dance in Indonesia, looks at, observes, and focuses on five contemporary Indonesian choreographers: Martinus Miroto (Yogyakarta), Mugiyono Kasido (Surakarta), Hartati (Jakarta / Padang), Jecko Siompo (Jakarta) / Papua), and Eko Supriyanto (Surakarta / writer). The development and change in form and creativity of each choreographer seen from the point of view of changing professionalism, their relationship with institutions to individuals, and the role of the government as a force of national identity. The process of creating the dance, he revealed that there are phases of dance creation, which include: (1) Re-Visiting, always revisiting cultural sites, conducting research, inviting them to preserve native Indonesian culture, (2) Re-Questioning: re-questioning the origin the origin of Indonesian culture, by knowing and understanding cultural history, the maintenance process will be easier and more conducive to carry out. (3) Re-Interpreting: reinterpreting with newness elements, without completely eliminating the original tradition, is also a form of cultural maintenance that is conditioned by the times. However, by sticking to the original elements, people will still recognize the origin of this novelty art. The phases of dance creation by Eko Supriyanto are of course not dance creation intended for educational needs, but rather artistry [11]. However, there are several phases that are suitable for the children's dance creation phase for this research, namely the re-visiting, requestioning and re-interpreting phases.

\section{Analisys of Concept}

If we examine the concepts of Gilbert [7] and McCutchen [6] above, there will be similarities in their writings. What they have in common is that they both carry the concept of construction in children's dance wrapped in the concept of educational dance. If you look at age, the concept of both tends to be concentrated on choreography with ages 2 to 12 years, where the age group is further divided from the age group of 2 years, 3-5 years, 6-8 years and 9-12 years. Each group has a burden that is not the same on the learning outcomes. The basics of the dance elements that are learned tend to be the same, such as the concept of body, body parts, body movements, body actions, steps, balance support, body shape, static. Space, shape, level, direction, measure of motion, place, focus, path, increment, distance. Energy, array, power, dynamics, load weight, strength, flow, attack, quality. Time, accent / focus point, beat, duration, pace, and rhythm. The equation is, if each meeting has the same approaches and techniques, such as Warming Up for warming up, Exploring 
the Concept is exploring the concepts that will be studied first, such as exploring student experiences with a duet, threes and by using properties and combining motion. Developing Skill, which is developing movements that already exist or have been formed in the process of exploration and improvisation. Creating, namely shaping motion through a process of improvisation and exploration which is structured according to the child's age. And, Cooling Down is resting the body interspersed with seeing performances and discussing them and making criticisms. From the learning process of these experts, the researcher took the core of the staple by adding several processes not mentioned above and became a process of steps in creating a new children's composition. The ENGKLE concept is the concept of creating dance compositions. In this context, the researcher develops a concept. The ENGKLE concept has the following steps. a). Enter Environments are more likely to return to nature, return to the environment to look back, ask questions about art contexts that exist in society. This concept is often used when the choreographer starts the process of creating a dance. b) Navigation is the concept of exploration or deepening of the basic elements of dance, the principles of dance forms, group dance composition, floor design, top design, property and stage. c). Googling is the concept of searching for the possibility of developing existing choreographic forms. d). Knitting and Validating, knitting is the concept of knitting back or standardizing parts of dance composition, then applied to children to measure the effectiveness of syntax that has been done and is called the concept of validation. e). Locking and presenting is the activity of locking or standardizing dance compositions. f). Evaluation is an activity of evaluating work after performance, all concepts of children's dance composition are measured and assessed by the assessment standards that have been made [12].

\section{CONCLUSION}

Anne Green Gilbert, Brenda Pugh McCutchen, Jacqueline Smith, and Larry Lavender are more inclined towards the process without specifying the formation of the choreography at the choreography formation stage because it aims at educational dance in the classroom, while Alma M. Hawkins, Sardono W. Kusumo, Eko Suprianto are more likely to the creation of pure dance with great attention to aesthetic aspects, meaning and symbolization in the steps of its formation because it aims to be pure artistic works. The ENGKLE concept is the essence of several dance creation concepts.
Herein lies a blend or a meeting of concepts from the West and concepts from the East. The ENGKLE concept itself can be used in the creation of creative, educational and pure dance. The ENGKLE concept consists of: Enter Environment, Navigation, Googling, Knitting and Validating, Locking and presenting and Evaluation.

\section{ACKNOWLEDGMENT}

This research is part of a dissertation research on the creation of children's dance choreography based on children's games. The author also thanks and sincerely to Prof. Juju Masunah, P.hD., Prof. Dr. Tati Narawati, M.Hum. and Dr. Trianti Nugraheni, M.Si., as well as for all colleagues from the Faculty of Art and Design Education, Universitas Pendidikan Indonesia who provide insights and expertise that are very helpful for this research.

\section{REFERENCES}

[1] S. Murgiyanto, Koreografi. Jakarta: Departemen Pendidikan dan Kebudayaan, 1992.

[2] S. Hadi, Dasar-Dasar Koreografi Kelompok. Yogyakarta: Institut Seni Indonesia, 1964.

[3] J. Smith, Komposisi Tari: SebuahPetunjuk Praktek Bagi Guru, Terjemahan Ben Suharto. Yogyakarta: Ikalasi, 1985.

[4] P. Irawan, Metodologi penelitian administrasi. Jakarta: Universitas Terbuka, 2006

[5] D. Schiffrin, Ancangan Kajian Wacana. Yogyakarta: Pustaka Belajar, 2007

[6] B.P. McCutchen, Teaching Dance as Art in Education. United Sates Human Kinetics, 2006.

[7] A.G. Gilbert and H.P. Smith, Creative dance for all ages: A conceptua approach. Reston, VA: American Alliance for Health, Physical Education, Recreation and Dance, 1992.

[8] A. Hawkins, Mencipta Lewat Tari (Terjemahan Subandiyo Hadi) Yogyakarta: Manthili, 2003.

[9] L. Lavender, Dancers Talking Dance: Critical Evaluation in the Choreography Class. Human Kinetics, vol. 1, 1996.

[10] F.X. Widaryanto, Ekokritisme Sardono W. Kusumo: gagasan, Proses Kreatif, dan Teks-teks Penciptaannya. Surakarta: Institut Seni Surakarta, 2015

[11] E. Supriyanto, T. Haryono, and S. Murgiyanto, "Empat Koreografer Tari Kontemporer Indonesia Periode 1990-2008," Panggung, vol. 24, no. 4 2014.

[12] A. Sunaryo, T. Narawati, J. Masunah and T. Nugraheni, Exploring Engkle Learning Model for Prospective Teacher in Creating GameBased Children Dance Composition. In International Conference on Arts and Design Education (ICADE 2018). Atlantis Press, 2019. 